\title{
Шапинская Е.Н.
}

К 450-летию Уильяма Шекспира.

\section{Музыкальная фантазия на тему «Бури»: интерпретация шекспировской пьесы языком современной оперы}

Аннотация: В статье рассмотрена проблема интерпретации классического художественного произведения языком современного искусства. Проведен анализ оперы современного композитора Томаса Адеса «Буря» на сюжет пьесы Шекспира и ее сценического воплощения. Автор раскрывает важность фантазийного момента в пьесе Шекспира, который помогает композитору раскрыть ряд проблем человеческого бытия, морали, власти, любви в сказочной форме, что подчеркивает универсализм этих проблем. В статье также поднята проблема трансляции смыслов произведения посредством иной культурной формы и в ином историко-культурном контексте. В работе используются методы текстуального анализа источников (материалов публикаций, посвященных анализу произведения Т.Адеса и его сценическому воплощению), а также семантического анализа культурных текстов (литературы и оперы). В статье также содержатся элементы компаративистского анализа. Новизна исследования заключается в постановке проблемы интерпретации классического произведения не только языком другой эпохи, но и другой культурной формы, что создает сложную интерпретативную матрицу. Кроме того, автор вводит в пространство исследований шекспировской тематики творчество Томаса Адеса, одного из интереснейших композиторов нашего времени, который создал оригинальную и талантливую версию «Бури» Шекспира для современной оперной сцены.

Review: The problem of interpretation of a classical work of art with the help of modern artistic language has been examined in the paper. Opera "The Tempest" by the contemporary British composer Thomas Ades based on the play by Shakespeare and its stage representation have been analysed. The author shows the importance of fantasy element in Shakespeare's work which helps the composer to show a number of problems of human existence, morals, power, love in a fairy-tale form, which accents the universality of these problems. The article also poses the problem of translating the meanings of the work in a different cultural context and in another cultural form. Methods of textual analysis of materials concerning the work of Th.Ades and its stage representation have been used as well as semantic analysis of cultural texts (the literary source and the operatic text). Elements of comparative study are also present in the paper. The novelty of the research work is in posing the problem of interpretation of a classical work not only by the language of a different period, but by another cultural form, which creates a complicated interpretative matrix. The author introduces into the field of Shakespearean studies the work of Thomas Ades, one of the most interesting composers of our time, who created an original and talented version of "The tempest" by Shakespeare for contemporary opera scene.

Ключевые слова: классика, культурная форма, интерпретация, музыка, художественная культура, образ, фантазия, трансляция, смысл, проблематика произведения.

Keywords: классика, культурная форма, интерпретация, музыка, художественная культура, образ, фантазия, трансляция, смысл, проблематика произведения.

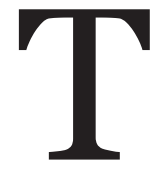

ворчество Шекспира привлекало и привлекает к себе внимание композиторов, которые воссоздают его произведения в самых разных музыкальных формах. Оперы, балеты, симфонические произведения на сюжеты шекспировских трагедий и комедий вошли в музыкальное мировое наследие и стали частью репертуара многих исполнителей. Загадка Шекспира, о которой так много писали исследователи, заключается не только (и не столько) в загадочных моментах его биографии, сколько в 
безграничном смысловом богатстве его творчества, которое доступно интерпретациям в самых разных жанрах и стилевых направлениях. Трудно найти другого классика, сюжеты и проблематика которого так по-разному осмысливались и так легко перемещались в самые разные культурные, темпоральные и социальные контексты. Наследие Шекспира перелагалось языком живописи, кино и музыки, причем каждый из этих языков искусства должен был максимально использовать свои выразительные средства, чтобы создать текст, соответствующий первоисточнику как в нарративном, так и в психолого-эмоциональном аспекте. Существует громадное количество работ, посвященных интерпретациям шекспировских произведений в различных видах искусства, но мы, претендуя на философское осмысление музыки, обратимся к той интерпретации, которая ведет нас к поискам ответа на два вопроса. Во-первых, это проблема трансляции смыслов при помощи языка и возможности интерпретировать культурный текст, созданный в определенном хронотопе, в терминах другого времени и другой культурной формы. Второй вопрос касается доминантных культурных смыслов: какие проблемные области произведений Шекспира выступают на первый план в различных интерпретациях сегодня, указывая тем самым на культурные доминанты нашего времени и ставя вопросы, касающиеся нашего бытия здесь-и-сейчас.

Для поиска ответов на эти вопросы мы обратимся к опере современного английского композитора Томаса Адеса «Буря» (либретто Мередит Оукс по пьесе Уильяма Шекспира). Мировая премьера оперы состоялась в Лондоне, в Королевском оперном театре Ковент Гарден 10 февраля 2004 года, и с тех пор ее успешно ставили на сценах ведущих оперных театров. Для нас это современное прочтение пьесы Шекспира представляет интерес именно с точки зрения возможности трансляции смыслов шекспировской трагикомедии языком другой культурной формы и другой эпохи. Опера Т.Адеса представляет собой не только и не столько произвольный перенос времени действия в иной контекст, сколько переложение этой весьма неоднозначной и трудной для толкования пьесы на язык современной музыки. Представляется симптоматичным сам выбор шекспировского текста для такого рода интерпретации. «Буря» (1610-1611) - одна из последних пьес в творчестве Шек- спира, которую традиционно относят к жанру трагикомедии. «Своеобразие метафор и аллегорий в так называемых «проблемных» и «романтических» драмах последнего периода состоит в том, что они усиливают свойственную этим пьесам дидактическую направленность, заостряют те или иные «проблемы», служат созданию атмосферы чудесного, сказочного начала, помогающего разрешению трагических по своему характеру конфликтов, подобно тому как в сказках они заканчиваются победой добра и всеобщим примирением. " ${ }^{1}$

На протяжении двух веков пьеса не была востребована у публики, однако начиная со второй половины XIX в. слава «Бури» стала расти, и её начали относить к величайшим созданиям шекспировского гения, считать своего рода художественным завещанием автора.»В целом философский замысел Шекспира ... сложен: «Буря» - это аллегорическая поэтическая сказка, в которой Шекспир ставит вопрос о средствах преобразования мира и человеческого общества, это своеобразная «драматическая утопия», отразившая античные и ренессансные идеи о наилучшем государственном устройстве, о роли науки, искусства, любви и поэзии в жизни общества, а также воздействие на Шекспира многих рассуждений Монтеня о жизни диких племен, о их нравах и обычаях, о социальном неравенстве и собственности.» ${ }^{2}$ Переложение драматургии Шекспира на язык другой культурной формы, в данном случае, на язык музыки представляет несомненную трудность и вызов композитору, осмелившемуся представить произведения великого классика через другой культурный код. Тем не менее, судьба «Бури» в музыкальном мире была достаточно интересной - сочинения на тему шекспировской драмы были написаны М. Локком и Г. Пёрселлом, Я. Сибелиусом и П.И.Чайковским, а в наши дни к ней обратился Томас Адес, получивший известность благодаря своему творческому переосмыслению различных музыкальных форм. Композитор проявил эту способность в самом начале своего творческого пути, написав полноценный вокальный цикл под названием «Пять ландшафтов по Элиоту». Томас Адес - во многом эпатажный композитор. Тем не менее,

\footnotetext{
${ }_{1}$ URLhttp://www.w-shakespeare.ru/library/metafori-iallegorii-v-proizvedeniyah-shekspira26.html.

2 http://www.w-shakespeare.ru/library/metafori-iallegorii-v-proizvedeniyah-shekspira26.html
} 
в отличие от многих композиторов, пытавшихся написать оперу на сюжет «Бури» и потерпевших неудачу, Томасу Адесу удалось не только завершить работу над музыкальным переложением сюжета, но и воплотить свое произведение на сцене. В ней проявилась важная особенность музыки композитора - ее коммуникативное качество, что отмечает английский певец Филип Лэнгридж, известный своим талантливым исполнением музыки современных композиторов, в частности Б.Бриттена (с которым нередко сравнивают Т.Адеса): «...он нисколько не похож на Бриттена... Он обладает своим собственным голосом. Томас общается через музыку. Если вы подумаете о современной музыке, то увидите, что мало кто действительно делает это. Музыка «Бури» достаточно сложна, но в ней есть другое качество - каждый персонаж имеет собственную вокальную характеристику. ... Для меня самой важной чертой Томаса является его способность к коммуникации. И в этом он похож на Бриттена». ${ }^{3}$ Не менее важным для успеха этого музыкального «прочтения» шекспировской пьесы стало понимание композитором культурного кода автора, без которого происходит разрыв с оригиналом, «преступание» границ интерпретации и создание произведения, лишь механистически, через сюжетные структуры связанное с первоначальным культурным текстом. (Последнее весьма часто встречается в современных культурных практиках интерпретации, особенно кинематографической). У Адеса присутствует «...инстинктивное ощущение пульса драмы, его безошибочное чувство магического, которое может стать ключом к «смелому новому миру», где грехи родителей не должны сказываться на детях».4

«Буря» - опера XXI века, единственное полноценное музыкальное произведение, охватывающее весь сюжет шекспировской пьесы. С музыкальной точки зрения, Адес довольно редко использует традиционную мелодику, (хотя в необходимых для этого по смыслу местах в опере присутствует замечательный мелодический лиризм), что делает его произведения трудными для исполнения, до предела нагружая как вокалистов, так

\footnotetext{
${ }^{3}$ Extract from an interview with Philip Langridge for MusicOMH” URLhttp://www.musicomh.com/classical_features/philip-langridge_0307.htm

4 Edward Seckerson, The Independent, 14 March 2007. URLhttp://enjoyment.independent.co.uk/music/reviews/article2356644.ece.
}

и оркестр. Это не может не вызывать отторжения у той части критики и публики, которая настроена на традиционный мелодический лад и не разделяет поисков модернистского музыкального языка. “ Музыка Адеса... конечно, не додекафония, мелодии там есть, но мало. Немного напоминает Бриттена, но Бриттен гораздо изобретательнее. Достоинства партитуры Адеса лежат в основном в оркестровой части, вокальная строчка у него почти лишена мелодий, не очень интересна и трудна для певцов.» 5 Не удивительно, что такой вокал вызывает неоднозначную реакцию даже со стороны профессионалов. «...что касается музыки Томаса Адеса, на то она и музыка, что ее язык интернационален. Именно это обстоятельство и склоняет назвать оперную napmumypy «Бури» какой угодно музыкой, но только не оперной, ибо в опере, прежде всего, принято петь: вокал в опере - это ее душа, а без души этого чрезвычайно условного, но такого эстетически прекрасного музыкального жанра попросту не существует. «Буря» Адеса - это ураган, который мы неосторожно впустили в себя, ибо он сметает всё на своем пути, сжигая мосты за собой... Так что определенно не до музыки тут, а главное, - не до волнующего слушательскую душу оперного пения... ${ }^{6}$ Возражая столь однозначному отрицанию мелодики в опере Адеса, можно привести многочисленные отзывы музыкальных критиков, распознавших в этом «урагане» вкрапления весьма традиционных мелодических элементов. Мы ни в коем случае не претендуем на иследование музыкальной составляющей оперы Tомаса Адеса - данная задача принадлежит музыковедам. Но, поскольку речь идет о произведении, созданном совсем недавно и мало известном у отечественной публики, представляется необходимым прибегнуть к некоторым элементам описания музыкальной стороны произведения, чей литературный первоисточник хорошо знаком, но музыкальная составляющая не столь известна. Чтобы избежать неопределенности очертаний предмета нашего исследования, отметим все же, что музыкальный язык композитора является диссонантным и по большей части атональным, усложненным в отношении инструментовки и гармонии, хотя сам автор называет свою музыку тональной. На наш взгляд, именно «Буря» Шекспира с ее фантастическими персона-

\footnotetext{
${ }^{5}$ http://arashi-opera. livejournal.com/1238885.html ${ }^{6}$ Корябин И. Опера «Буря» Томаса Адеса в Метрополитен-опере. // http://www.belcanto.ru/12120302.html
} 
жами, смешанными чувствами и неоднозначным финалом как нельзя больше подходит к переложению таким языком. Фантазийность всего происходящего усиливается «странной» музыкальной характеристикой тех персонажей, которые и сами носят фантастический характер, прежде всего, Ариэля, Калибана и, конечно, Просперо, который силой своего волшебства может творить и разрушать фантазию. О связи фантазийного элемента с музыкой писал еще В.Г.Белинский в рецензии на третью книжку «Пантеона русского и всех европейских театров» за март 1840 года, который издавался тогда в Санкт-Петербурге: “"Буря” Шекспира - очаровательная опера, в которой только нет музыки, но фантастическая форма которой производит на вас самое музыкальное впечатление». А чуть далее, говоря о рецензируемом прозаическом переводе «Бури» Шекспира, сделанном М. А. Гамазовым, великий русский критик, восторгаясь вкрапленными в него стихотворными вставками, цитирует стихи песни Ариэля и восклицает: «Какая роскошная фантазия! Она раскрывает таинственные убежища замкнутых в явления духов жизни, дает им причудливо обольстительные образы и населяет ими и небо, и землю, и воды, и леса... Вот истинный мир фантастического!.. Но в “Буре" много и других элементов: тут и высокая драма, и смешная комедия, и волшебная сказка. И всё это так слито, так проникнуто одно другим и составляет такое чудное целое!.. “Буря” - прекрасный сюжет для оперного либретто, если бы искусная рука взялась за него». ${ }^{7}$ Имманентная музыкальность «Бури» стала, на наш взгляд, одной из главных причин успеха оперы Т.Адеса. Парадоксальность мира, которая присутствует во многих произведениях Шекспира, наиболее ярко выражена в «Буре», являясь логическим завершением этой линии творчества Шекспира в целом. Другой важной стороной его метода является сочетание реального с фантастическим. Его художественное видение органично соединяет мифическое, легендарное и сверхъестественное с логикой реальных событий и психологически обоснованным поведением персонажей. Фантастические мотивы, сказочные сюжеты роднят Шекспира с фольклорной традицией, рыцарским романом и наиболее ярко проявляются в его поздних пьесах, которые называ-

\footnotetext{
7 Цит. по: Корябин И. Опера «Буря» Томаса Адеса в Метрополитен-опере. URLhttp://www.belcanto. $\mathrm{ru} / 12120302 . h t m l$
}

ют трагикомедиями и с которыми связывают романтические традиции в его творчестве. В них есть то, что характерно для романтического умонастроения: тяга к неизвестному, прорыв к идеальному, чувство непостижимости, алогичности мира, представление о жизни как о сплетении не обусловленных друг другом событий. ${ }^{8}$

Мечта русского критика воплотилась в XX1 веке, что опровергает утверждения об исчерпанности возможностей классики для создания новых культурных текстов, а также во много служит ответом на упреки, которые так часто раздаются в адрес современных оперных постановок по поводу неуместности эпатажных режиссерских экспериментов по отношению к оригиналу. В данном случае композитор взял на себя смелость заново рассказать историю волшебника Просперо своими музыкальными средствами. Учитывая «странный» характер персонажей этой пьесы, а также присутствующую в ней идею об относительности реальности, можно сказать, что сложная и непривычная для слуха музыка Т.Адеса очень выразительно передает и изысканную легкость Ариэля, и монструозность Калибана, и душевный разлад Просперо, и лиризм влюбленных. Эти образы требуют отхода от традиционной интерпретации, как в драматическом, так и в музыкальном отношении и представляют собой благодатный материал для творческих экспериментов. «Мы созданы из вещества того же,// Что наши сны.// И сном окружена// Вся наша маленькая жизнь.» - эти слова Просперо могли бы стать эпиграфом к любой значимой интерпретации пьесы, которая стремится передать неуловимую атмосферу реально-нереального царства Просперо, некоего сюрреалистического пространства, где «реальные»персонажи, кажущиеся здесь неуместными, попадают под власть чар, которые, в свою очередь тоже неизбежно разрушаются, оставляя лишь монструозного Калибана на покинутом острове.

Выразить столь неуловимую грань и взаимопереход между сном и реальностью на вербальном языке очень трудно, отсюда привлекательность «Бури» для создателей визуальных образов. В этой связи обратимся еще

\footnotetext{
8 Это наблюдение сделано в связи с иллюстрациями к «Буре» Дж. Бойделла. См.: Воронина T.C. Шекспировская галерея Джона Бойделла. - В кн.: Магия литературного сюжета. проблемы интерпретации в изобразительном искусстве. М., Памятники исторической мысли, 2012. С.262
} 
к одной интерпретации «Бури» - к фильму П.Гринуэя «Книги Просперо» (1991г.) Усложненная образность режиссера, использовавшего в своем фильме самые передовые на момент его создания технологии, как нельзя лучше создают зыбкий и причудливый колорит царства Просперо (Джон Гилгуд), который предстает мудрым старцем. (Актеру на момент съёмок фильма было уже 87 лет) . Воплощение «Бури» киноязыком было многолетней мечтой Гилгуда, которой было суждено осуществится как финальному аккорду его жизни и карьеры. Рассматривая историю постановок «Бури», невозможно не обратить внимания на странные совпадения, больше соответсвующие миру сновидения, чем реальной работе «культурной индустрии». Гилгуд мечтал сделать фильм по «Буре», находя волшебный элемент пьесы прекрасно подходящим для экрана - и, так же как и у Шекспира, этот фильм стал венцом и своеобразным итогом его творческой деятельности. Сценарий фильма был написан Гринуэем специально для Гилгуда, точно так же, как и роль Просперо у Адеса была написана для Саймона Кинлисайда, создавшего экспрессивный и трагический образ разочаровавшегося во всех своих жизненных ценностях человека. (За эту роль исполнитель получил престижную премию Лоуренса Оливье). Сам он так оценивает это произведение: «Буря» была необыкновенно значима. Это великое произведение великого оперного канона. Композиторам трудно писать произведения. которые и доступны, и интересны для воображения. Но в данном случае мы имеем дело с великолепной музыкой, которая в то же время доступна» .9

Просперо - сложный образ, и если он удается, то становится вершиной в творческой судьбе исполнителя. В фильме Гринуэя на нем сосредотачивается все действие, оставляя остальным персонажам место окружения, статистов, фона волшебного существования Просперо. Если персонаж Гилгуда воплощает мудрость и понимание жизни, основанное на опыте всей жизни, то герой Саймона Кинлисайда не избавлен от чувства мщения и ненависти к тем, кто предал его, и эта ненависть становится движущей силой его поступков. «В опере Просперо, оставаясь «всевышним регулировщиком» событий и автором, то есть устроителем бури, не мягок и благороден, как у Шекспира, а мстителен и жесток: ради счастья дочери жизнь

${ }^{9}$ URLhttp://www.theguardian.com/profile/nicholaswroe на острове он превратил в сущий ад, о чем в финале оперы своему бывшему повелителю и говорит навсегда покидающий его дух ветра Ариэль. Но, что очень важно, фатальным моментом для Просперо согласно либретто является чувство любви, вспыхнувшее между Мирандой, его дочерью, и Фердинандом, сыном его врага, Неаполитанского короля: сила этой любви оказывается выше могущественных чар и чудодейственных познаний Просперо, полностью побеждая их.» ${ }^{10}$

Поскольку мы настаиваем на важности визуального элемента в интерпретациях «Бури», нельзя не сказать, что он играет важнейшую роль как в фильме Гринуэя, так и в спектакле Лепажа, хотя конструкция волшебного царства Просперо совершенно разная. Если у Гринуэя оно представляет собой сложную многомерную конструкцию, воплощенную как талантом Гринуэя-художника, так и всеми доступными ему техническими средствами, то Лепаж представляет мир иллюзий Просперо как интерьер театра Ла Скала XIX века, прибегая к довольно распространненому приему «театра в театре». Возможно, сценическое решение Лепажа не приемлемо для многих критиков, как и музыка Адеса. Как и всякое сложное по архитектонике произведение (а таким, вне сомнений, является «Буря» Адеса - Лепажа) опера служит поводом для самых разнохарактерных, вплоть до противоположности мнений, причем это связано не столько с квалификацией авторов, дающих столь разнородные отзывы, сколько с гетерогенностью самого музыкального и драматического материала, с семантическим богатством спектакля. Что касается визуального решения образа Просперо, очень важного для образного ряда всей постановки в целом, поскольку он является повелителем и властителем этого царства, оно также совершенно различно в том и другом случае. У Гринуэя Просперо находится в конце жизненного пути (что во многом связано как с возрастом, так и с профессиональным опытом Джона Гилгуда). Образ как бы вторит творческой и жизненной судьбе исполнителя, который подводит итог жизни, отказываясь от своего главного сокровища - книг, утверждая этим приоритет жизненного опыта над книжным знанием. «Книги Просперо» стали финальной жизненной декларацией как великого актера, так и его умудренного жизнью героя.

\footnotetext{
${ }^{10}$ Корябин И. Опера «Буря» Томаса Адеса в Метрополитен-опере//URL http://www.belcanto.ru/12120302.html.
} 
«Пение, музыка, танцы нимф - весь театральный праздник порождает у Просперо образное суждение о жизни: когда-нибудь все в мире растает, как эти видения, и даже великий земной шар растворится без следа: «Мы сотканы из той же ткани, что и сны, и наша маленькая жизнь окружена сном». Решение Просперо отказаться от волшебной власти не означает примирения мудреца со злом, это всего лишь признание, что жизнь человеческая имеет предел, что даже мудрейшие люди когда-либо исчезнут - как все, что существует. Просперо осуществил свои цели - он восстановил справедливость, сделал людей лучше, наказал преступление, вернулся в мир людей и даровал счастье дочери и юному принцу, он повелевал стихиями и людьми, но и он признает, что силы человека не беспредельны, в этом смысл грустного финала волшебной поэтической сказки. «"11 Просперо Саймона Кинлисайда гораздо моложе (что вполне логично, учитывая возраст его юной дочери) и гораздо фантастичнее. Покрытый татуировками, с перьями в волосах, он напоминает причудливые фигуры фильмов в стиле фэнтези, вполне соответствуя популярным представлениям о чародеях. Амбивалентность Просперо, который не является ни добрым волшебником детских сказок, ни злым колдуном, находясь в маргинальном положении по отношению как к тем, так и к другим, оправдывает этот странный облик, не лишенный некоей притягательности. «... ближе к финалу, где скорбь и внутреннее опустошение Просперо почти физически ощущаются через музыку, несмотря на то, что в это время на сцене все со всеми мирятся и благословляют счастливых влюблённых Миранду и Фердинанда. А Просперо одинок и потерян, даже Ариэль оставил его, вернувшись в свои заоблачные высоты. Образ Просперо в либретто не таков, как у Шекспира. $\mathrm{B}$ опере он более ожесточённый и замкнувшийся на идее мести персонаж. Даже прощает он, такое впечатление, не столько из великодушия, сколько от чувства бессилия и одиночества. Ему в конце очень сочувствуешь». ${ }^{12}$ В опере Адеса Просперо представляет собой противоречивую и харизматическую фигуру. С.Кинлисайд делает своего героя живым человеком, полным нежности к своей дочери Миранде и в то же время жестоким, жи-

${ }^{11}$ URLhttp://www.w-shakespeare.ru/library/metafori-i-allegorii-v-proizvedeniyah-shekspira26.html

${ }^{12}$ URLhttp://arashi-opera.livejournal.com/1238885.html. вущим ненавистью к своим врагам и жаждой мщения, которые он постепенно осознает как трагическую ошибку и отказывается от них. «Иногда через горечь Просперо проскальзывает еще живущая в нем любовь к красоте, заметная даже на фоне его гнева на непослушание дочери и его страх за нее». ${ }^{13}$

Визуальная конструкция образов «Бури», в особенности главного героя, важна, несомненно, не просто как декоративная составляющая постановки - она является фреймом, внутри которого реализуется сущность Просперочеловека, Просперо-волшебника, Просперо-отца, Просперо-правителя. Без сомнения, этот образ - ключевая фигура в «Буре», через которую проводится философия жизни Шекспира как итог всего пройденного пути.

«Вот так, подобно призракам без плоти,// Когда-нибудь растают, словно дым,//И тучами увенчанные горы,// И горделивые дворцы и храмы,// И даже весь - о да, весь шар земной.// И как от этих бестелесных масок,// От них не сохранится и следа». ${ }^{14}$ Эти слова Просперо, с одной стороны, несут в себе щемящую грусть ощущения бренности земного бытия, с другой - приближают героев и проблемы произведения к каждому человеку вне зависимости от времени, в котором он живет, поскольку время всегда быстротечно, и его внешние оформления в культурные формы лишь условность. «Вневременность» подчеркивается и постановкой Р.Лепажа. который сталкивает различные фантазийные и квазиреалистические образы в сценическом пространстве условности.

Доминирование фигуры Просперо как в опере, так и в фильме, несомненно, но в «Буре» Т. Адеса он -не единственный интересующий автора персонаж. Еще одним не менее оригинальным и интересным образом становится дух воздуха Ариэль. «...природа Ариэля такова, что он с трудом подчиняется даже разумному и доброму господину, он жаждет получить полную свободу и служит целям Просперо только временно, т. е. по природе творческие силы человека стремятся к свободе, однако они вынуждены подчиняться или злым или добрым силам, и их полная независимость от человеческого общества относительна- свободны лишь стихийные силы

${ }^{13}$ URLhttp://www.simonkeenlyside.info/index.php/performances/performances-opera/tempest-ades-prospero/2012-new-york-metropolitan-opera-the-tempest

14 У. Шекспир. Буря. - в кн.: Весь Шекспир. М., ОЛМА-ПРЕСС, 2002. С.871 
природы, но искусство должно быть подчинено власти разума». ${ }^{15}$

Вокальное и сценическое конструирование образа Ариэля еще более сложно, чем волшебника Просперо, не потерявшего все же своей связи с миром людей. Ариэль - дух воздуха, существо неуловимое, своеобразное воплощение миража сонного воображения. Эта воздушно-капризная сущность Ариэля передана в музыке невероятно сложными пассажами, представляющими явный вызов для исполнительницы (сопрано Одри Луна). Не менее причудлив и внешний облик этого персонажа.

Еще одним существом из волшебного мира острова Просперо является Калибан, воплощающий все худшие качества «природного» человека. Просперо, как бы споря с будущими деятелями Просвещения руссоистского толка, утверждает невозможность усовершенствования того, кому природой отказано во всем высоком и прекрасном. : «...Я научил// Тебя словам, дал знание вещей.// Но не могло ученье переделать// Твоей животной, низменной природы.» ${ }^{16}$

Калибан - фигура монструозная, находящаяся вне мира людей и вне мира духов, воплощение безобразия и невежества. «Его не в состоянии исправить никакое учение и никакое знание само по себе. Если понять образ Калибана шире, чем он непосредственно выведен в пьесе, а именно - увидеть в нем не просто грубого и невежественного туземца, а сатирическое изображение человечества, то весьма знаменательным начинает выглядеть скептическое отношение Шекспира к возможности самого по себе знания, просвещения сделать человека более порядочным. По сути дела, поэт не признает той главенствующей роли разума в истинно человеческом развитии, о которой так любят рассуждать философы. Человека делает человеком нечто совсем иное, нежели разум, - такой вывод можно сделать уже из одного этого высказывания Шекспира (или, по крайней мере, его героя - Просперо).»17

Образы Ариэля и Калибана часто получают аллегорическое истолкование, они создают контраст между властью искусства и низ-

${ }_{15}^{15}$ URL: http://www.w-shakespeare.ru/library/metaforii-allegorii-v-proizvedeniyah-shekspira26.html

16 У. Шекспир. Буря. - в кн.: Весь Шекспир. М., ОЛМА-ПРЕСС, 2002. С. 848

${ }^{17}$ Колчигин С. Буря в мировоззрении Шекспира. URLhttp://www.proza.ru/2011/o9/23/669) менными, грубыми страстями в человеческой природе. Это противопоставление насыщено множеством разных, слабо связанных друг с другом ассоциаций. Несомненно, что Ариэль воплощает силы природы и всех видов искусства: он умеет летать, плавать, вызывать гром, молнию, он не горит в огне, быстро мчится на облаках, он воспроизводит рев морской бури, возбуждает видения в воображении людей, он обладает властью не только над природой, но и над чувствами людей, вызывает любовь в сердцах Миранды и Фердинанда, раскаяние в душе Алонзо, страх Себастьяна и Антонио, даже Калибан поддается воздействию волшебной музыки. Ариэль символизирует власть искусства над людьми, особенно власть театра - его «чудеса» могут восприниматься и как театральное представление.

Просперо обращается с Калибаном как с нижестоящим существом, с рабом, который не заслуживает ни сочувствия, ни понимания. Согласно сюжету, это объясняется тем, что когда-то Калибан пытался обесчестить Миранду, и потому Просперо был вынужден применить к нему принуждение. Кроме того, Просперо признается, что только воспитанием не может изменить грубую природу Калибана. И он оказывается прав: Калибан восторженно приветствует шута Тринкуло и дворецкого Стефано, которым он за бутылку «божественного напитка» готов отдать и свою свободу и весь остров. Калибан уговаривает их убить Просперо, сжечь его книги и завладеть островом.» Эта аллегория говорит о том, что Шекспир разделял опасения гуманистов относительно народных мятежей: в драме показано, как бунт дикаря и пьяных слуг едва не закончился гибелью мудреца и волшебника. Весь бунт изображен в комическом свете, особенно смешно звучит в устах пьянчугидворецкого песенка, которая заканчивается припевом: «Мысль свободна». В аллегорической форме изображено бессмысленное и глупое бунтарство пьяниц и невежд, которые стремятся к «свободе» от труда и всяких законов, сдерживающих их низменные страсти. ${ }^{18}$ Таким образом, фантастический мир острова Просперо является аллегорией мира человеческого, в котором сталкиваются благородство и предательство, любовь и ненависть, мудрость и невежество, воплощенные в персонажах пьесы и «переведенные» на музыкальный язык Т.Адесом. Разрешение кон-

${ }^{18}$ URL: http://www.w-shakespeare.ru/library/metafori-i-allegorii-v-proizvedeniyah-shekspira26.html. 
фликта и в том, и в другом случае связано с победой жизненного начала над миром грез и снов, прекрасных и страшных, в которые погружено царство Просперо. Ближе к концу пьесы Просперо говорит о своем могуществе, способном активно воздействовать на природные стихии и тонкие элементы, т.е. о своих экстраординарных способностях. Однако от этого могущества он тут же и отказывается: «...Но ныне собираюсь я отречься// От этой разрушительной науки.// Хочу лишь музыку небес призвать, // Чтоб ею исцелить безумцев бедных, // А там - сломаю свой волшебный жезл// И схороню его в земле. А книги// Я утоплю на дне морской пучины,// Куда еще не опускался лот.» ${ }^{19}$

Причина отказа постигшего тайную науку Просперо может быть объяснена по-разному. Если рассматривать всю нарративную линию волшебства и реальности как их противостояние, выделять в качнстве главной проблему познания мира разными способами, можно считать финальное отречение Просперо победой светлого человеческого разума над темными силами сверхъестественного. Просперо называет их «разрушительной наукой», потому что понимает: «... не обеспеченная нравственными качествами, эта наука становится опасной для человека и окружающей его природы. Чудеса - не синоним человечности. Человек без волшебных способностей не перестает быть человеком. А вот обладающий сверхъестественными способностями, но лишенный внутреннего, душевного тепла, не может быть безоговорочно отнесен к представителям рода «Человек». ${ }^{20}$ Если же рассматривать внутренний конфликт Просперо с этической точки зрения, то на первый план выступает другая идея. «... нельзя не заметить, что лейтмотивом и всей «Бури» является именно идея милосердия как главного признака человека. Не разум, не творчество, не сила и не волшебство (паранормальные способности) составляют сущность человека как такового. В этом, кстати, легко обнаружить разительное отличие шекспировского мировоззрения от современной мифологии, от популярных литературных произведений, где успешно действуют дети-волшебники, старцы-колдуны, непобедимые рыцари, чародейки-феи и т.д. и т.п. В этом же заключен разительный кон-

19 У. Шекспир. Буря. - в кн.: Весь Шекспир. М., ОЛМА-ПРЕСС, 2002. С.873

${ }^{20}$ Колчигин С. Буря в мировоззрении Шекспира http://www.proza.ru/2011/o9/23/669). траст мировоззрения Шекспира, как оно выражено в «Буре», и со всей наукой, вплоть до ее современного состояния. Вот почему Ариэль с тихой грустью произносит фразу о короле Алонзо и его свите: «Будь я человеком, Мне было бы их жаль...» Ариэль, всепроникающий бестелесный дух, безусловно разумный, к тому же обладающий колоссальными, сверхчеловеческими и творческими способностями, оказывается, лишен того качества жалости, сочувствия, шире говоря - доброты, которое свойственно одному лишь человеку! Это-то дополнительное и сущностное качество и отличает человека от всех чудотворцев и могущественных духов. Поскольку это так, постольку становится понятным все дальнейшее развитие событий в шекспировском произведении. Становится ясным, почему волшебник Просперо отрекается от своего дара. ${ }^{21}$ Но есть еще одно объяснение краха жизненных устоев Просперо, которое очень явно эксплицировано в опере Адеса. Могущественный волшебник, научившийся повелевать духами, подчиняющий себе стихии, оказывается бессильным перед властью любви, которая соединила его любимую дочь Миранду с сыном его заклятого врага. . В течение вечера мы видим, как он меняется, пока наконец, в потрясающем монологе 3 акта он не обвиняет самого себя в том, что он принес адские муки на ранее невинный остров. Он клянется утопить свои книги, сломать свой волшебный жезл, он даже отказывается от Миранды. Восстановив порядок в придворном обществе, он теряет к нему интерес. Он умоляет освобожденного Ариэля остаться, но в из связи не было любви и дух улетает на свободу. Отчаяние Просперо никогда не чувствовалось так реально.» ${ }^{22}$ Просперо побежден силой любви, он уступает ей не по собственной воли, а с осознанием того, что она сильнее всех его сверхъестественных способностей, что вся его наука, которой он отдал всю жизнь, весь его праведный гнев уничтожены любовью двух молодых людей. В музыке противоречие между миром Просперо, исполненным мрачных диссонансов, и в миром влюбленных, где композитор вводит элементы традиционной мелодики, ощущается на чувственном уровне, создавая впечатление разорванного и растерзанного мира

${ }^{21}$ Колчигин С. Буря в мировоззрении Шекспира http://www.proza.ru/2011/o9/23/669.

22 URL: http://www.simonkeenlyside.info/index.php/ performances/performances-opera/tempest-ades-prospero/2012-new-york-metropolitan-opera-the-tempest/. 
Просперо, который уступает любой им дочери, теряя свою собственную силу и самость. Обретенное им положение в мире людей не компенсирует того мира, который он мог строить по своим желаниям. Любовь как величайшая сила в мире в то же время и разрушительна - эта амбивалентность любви, о которой говорили еще поэты времен античности, соединяет юных влюбленных, в то же время обрекает на вечные страдания Калибана, дает свободу, но не дает любви Ариэлю, лишает Просперо всего, что он создал за свою жизнь. Осознавая и признавая великую силу любви, авторы и интерпретаторы «Бури» ставят под сомнение ее как универсальное благо. С. Кинлисайд очень тонко передаёт эту «внезапную опустошенность, настигающую Просперо своеобразным озарением, осознанием и осмыслением того, что любовь как основа всего сущего обладает такой непостижимой ценностью, против которой любая магия не столько бессильна, сколько кощунственна. Герой Кинлисайда , переживший крушение идеалов, надежд и веры в людей, а потому имеющий право влиять и повелевать. Но власть, лишенная вдумчивости, трезвости и милосердия, не просто разрушает всё, к чему прикасается (в этом нет ничего нового), но разрушает и самооценку, самоуважение своего носителя! Просперо перестаёт нравиться сам себе, когда понимает, что губит счастье собственной дочери, а ему не безразлично его собственное поведение, и этот гуманистический бихевиористский акцент имеет важнейшее значение для понимания актуальности этого произведения именно в наши дни, когда мы, прикрываясь цинизмом борьбы за самосохранение, активно утрачиваем этот ценный навык, этот важный ориентир в мире наших желаний и устремлений - чувство самоуважения... И то, что артисту удаётся передать этот сложнейший ядерный смысл непростой оперы Адеса, - большая удача, настоящий подарок». ${ }^{23}$

Рассмотрев различные аспекты «Бури» в еe музыкально-сценическом воплощении, попробуем дать ответы на поставленные вначале вопросы. Во-первых, вопрос о языке культурной формы. Мы говорим о тексте современной культуры (в данном случае «Буре» Томаса Адеса»), основой для которого послужил другой культурный текст, созданный в совершенно другую эпоху. Хотя язык первоисточника и язык созданного на его основе

\footnotetext{
${ }^{23}$ Курмачев A. He Sandy, но все-таки буря. URL-
} http://www.operanews.ru/12111803.html нового текста, лингвистической точки зрения могут быть наименованы как «английский», тем не менее это разные языки с точки зрения их темпоральной составляющей. Язык Шекспира передан в либретто Мередит Оукс с достаточной степенью упрощеностью, снимая, таким образомя. дистанцию оригиналу. Проблема, таким образом, двоякая: с одной стороны, язык современной музыки использован для передачи языка другой эпохи. С другой, само соотношение музыкального и вербального компонента в опере является весьма сложным, в отличие от «чистой» поэзии или «неосложненной» вокалом музыки. Кроме того, интерпретации текстов «другой» культуры (в лингвистическом смысле или в смысле разницы хронотопов) всегда предполагают межкультурные, вернее, кросскультурные связи, преодоление времени, пространства и лингвокультурных барьеров в творческом акте. Позволим себе привести пример из творчества композитора «Бури» Томаса Адеса в той же области музыкального переложения текста, написанного языком, уже вышедшим из употребления. Мы имеем в виду его произведение «Танец смерти». Этот сюжет, распространенный в Средние века, когда религия призывала людей помнить о стоящей всегда рядом смерти и раскаиваться в своих грехах, неожиданно обрел новую жизнь в музыкекомпозитора, представившего свой «Тоттентанц» в Лондоне в июне 2013. Как и сейчас, в эпоху средневековья художники, при помощи предписанных им установок в области репрезентации, пытались сказать что то о человеческой жизни и о том, что не обходит никого и никогда страхе смерти. ${ }^{24}$

Автор «Танца смерти» в его двух вариантах, любекском и таллиннском, Бернт Нотке был одним из крупнейших художников Северной Европы, имел большую мастерскую в Любеке, был известен во всем балтийском регионе. Его «Тоттентанц» в церкви святой Марии в Любеке был уничтожен во время Второй мировой войны, а таллиннский вариант существует по сей день и привлекает многих посетителей в церковь Нигулисте. «Бернт Нотке жил и работал в переходный период между эпохой Средневековья и ранней современности, между готикой и Ренессансом С одной стороны, он все еще соблюдал каноны средневекового искусства, с другой применял многие новые художественные и технические решения».

${ }^{24}$ См.: Козъякова М.И. История. Культура. Повседневность. М., Согласие, 2013. Сс. 234-239 
25 Новизна технических решений является приметой того, что художественная жизнь не стоит не месте, хотя сюжеты произведений искусства могут жить веками и тысячелетиями. Каждый художник переосмысливает их в соответствии с установками и ценностями своей эпохи и говорит о них присущим этой эпохе языком. Жизнь и смерть - базовые категории человеческого существования, вне зависимости от таких социальных и демографических показателей как продолжительность жизни, рейтинг самоубийств или наиболее опасные болезни. Смерть всегда рядом, как бы далеко не шагнула медицина и не повысился уровень жизни. Универсальность ощущения конечности земного бытия, выраженная в столь выразительной форме репрезентации отношений Человека и Смерти как «Танец смерти» привлекает к себе художников и музыкантов прошлого и настоящего. То, что сюжет этот неисчерпаем, показывает последнее обращение к «Пляске смерти» Томаса Адеса, прибегающего к весьма смелым выразительным приемам и достигающего великолепной выразительности и настроения. За основу «Тоттентанца» Адеса взята любекская композиция, уничтоженная во время войны. Этот факт символического уничтожения Смерти еще большим ужасом Войны, придал экспрессию музыкальной вокально- инструментальной композиции Адеса. Смерть в «Тоттентанце» Адеса в исполнении Саймона Кинлисайда предстает седуктивно-манящей, обращенной адресно к каждому персонажу. Различные жертвы Смерти исполнены меццо-сопрано Кристиан Стоджин, которая достигает эффекта индивидуальности и в то же время универсальности страха смерти у мужчин и женщин, молодых и старых. Экспрессия музыки, усиленная дирижерским мастерством Томаса Адеса делает «Тоттентанц» полностью созвучным нашему времени, в котором Смерть принимает новые обличья и стоит к человеку может быть даже ближе, чем во времена Бернта Нотке. «Тоттентанц» Томаса Адеса стал прекрасным воплощением в звуке этой зловещей и манящей темы. Слыша зов смерти в голосе Саймона Кинлисайда, можно поддаться ее очарованию, вступив в тот бессмертный танец, который испокон веков исполняется всем человечеством.

Этот опыт интерпретации текста, написанного на старонемецком языке и пересказанного самыми современными средствами

\footnotetext{
${ }^{25}$ Cм.: Anu Mand. Bernt Notke. Between Innovation
} and Tradition. Tallinn 2010. P.9 языка музыкального, заставляют задуматься об очень важной проблеме, которая в течение долгого времени тревожит исследователей самых разных направлений и возникает вновь и вновь в связи с возникновением новых культурных практик и расширением границ интерпретации. Расширяя традиционную проблематику взаимоотношений формы и содержания, можно выдвинуть предположение о первичности некоторых культурных универсалий, которые медиируются через разные культурные формы и культурные коды, не теряя своего основного смысла. То, что делает в своих работах Томас Адес, является столкновением двух миров. Мир означаемого - это мир пьесы (или фрески и старинной легенды), в котором сталкиваются разные «реальности», преломляющиеся через магию Просперо. В роли означающего выступает музыка, которая соотносится с миром острова Просперо только через характеристику внутренней сущности персонажей ( о чем мы писали выше). Что касается формы этого означающего - она является продуктом совершенно иного века, нежели первоначальный текст, и представляет собой палимпсест стилей, возникавших в прошедшие столетия и так или иначе отложивших отпечаток на комплексном музыкальном языке современных композиторов. Тем не менее, разрыв этот весьма формален, поскольку музыка полностью следует за динамикой сюжета, а главное - развития характеров. В особенности это относится к Просперо, который в конце приходит к полному краху своих ожиданий и, в то же время, к отказу от могущества, которое было направлено на деструкцию. Одно их самых значимых мест в шекспировской «Буре» - ее эпилог. Возможно, это намек на то, что в Эпилог вложены мысли не персонажа ее, а непосредственно самого автора пьесы: «Отрекся я от волшебства.// Как все земные существа, // Своим я предоставлен силам.// < ...> И дав обидчикам прощенье, // И я не вправе ли сейчас// Ждать милосердия от вас?// Итак, я полон упованья,// Что добрые рукоплесканья// Моей ладьи ускорят бег.// Я слабый, грешный человек,// Не служат духи мне, как прежде.// И я взываю к вам в надежде,// Что вы услышите мольбу,// Решая здесь мою судьбу.// Мольба, душевное смиренье Рождает в судьях снисхожденье.// Все грешны, все прощенья ждут.// Да будет милостив ваш суд» ${ }^{26}$

${ }_{26}$ У. Шекспир. Буря. - в кн.: Весь Шекспир. М., ОЛМА-ПРЕСС, 2002. С.876 
В Эпилоге оперы Томаса Адеса сливаются те лингвистические, музыкальные и визуальные коды, которые в причудливых сочетаниях составляют интертекстуальную основу произведения. На вопрос о языке столь сложной культурной формы как оперный спектакль, можно сказать, что он представляет собой полифоническое единство, причем голоса в нем имеют свою дистинктивную определенность, сохраняя связь со своими «хозяевами», частью идентичности которых они являются. Если с музыкальной точки зрения эту «отдельность» голосов можно рассматривать как экспериментальный ход эпатажного композитора, то с точки зрения культурной ситуации в целом, это вполне соответствует вниманию к Другому и его Голосу в контексте посткультурного плюрализма.

Здесь мы подошли ко второму вопросу: насколько доминантные культурные смыслы текста определяются контекстом существования культурного текста в его хронотопе. В истории Просперо-герцога и Просперо-волшебника заключены и размышления о природе власти, и идеи возможности контролировать судьбу другого человек, и кризис личностного начала, наступивший в результате преодоления собственной власти великой властью Любви. Но декларация Просперо «... Милосердие сильнее мести» в опере Адеса звучит не как торжество этических принципов, а как признание невозможности изменить ход событий по воле одного человека, хоть и наделенного волшебными способностями. Поражение Просперо - это поражение чудесного и фантастического, и если можно говорить о торжестве некоего принципа, то, скорее, это принцип повседневной реальности, опустошающий волшебный остров Просперо. В контексте наших дней, когда эскапизм в виртуально-чудесное постоянно пытается утвердить себя на фоне казалось бы терпящей поражение рациональности обращение к великой классике Шекспира показывает, что реальная жизнь со всеми ее противоречиями, ошибками, добром и злом гораздо более ценная для человека, чем иллюзии и сны, какую форму они не принимали. В этой жизни бессильно и полученное через постижение мудрости волшебство Просперо, и все чары фантазийного мира, поскольку в ней действуют иные законы. «Хотя натурализм - порождение девятнадцатого века, пишет Айн Рэнд в своем исследовании творческого процесса в литературе, - его духовным отцом был Шекспир. Одна из главных идей в творчестве Шекспира заключается в том, что человек не обладает свободой воли и его судьба предопределена врожденной «трагической ошибкой». ${ }^{27}$ Покинутый остров Просперо - это символ всех человеческих фантазий, мечтаний и иллюзий, которые в конечном итоге должны уступить детерминизму жизненной реальности.

\section{Список литературы:}

1. B Воронина Т.С.Шекспировская галерея Джона Бойделла.-В кн.: Магия литературного сюжета. проблемы интерпретации в изобразительном искусстве. М., Памятники исторической мысли, 2012

2. Козьякова М.И. История. Культура. Повседневность.М., Согласие, 2013

3. Колчигин С. Буря в мировоззрении Шекспира http://www.proza.ru/2011/og/23/669.

4. Корябин И. Опера «Буря» Томаса Адеса в Метрополитен-опере//URL http://www.belcanto.ru/ 12120302.html.

5. Рэнд А. Романтический манифест. Философия литературы. М., Альпина Паблишер, 2011.

6. У.Шекспир. Буря.-в кн.: Весь Шекспир. М., ОЛМА-ПРЕСС, 2002.

7. $\quad$ Anu Mand. Bernt Notke. Between Innovation and Tradition. Tallinn 2010.

8. Д. Ю. Густякова Массовая культура как контекст оперной постановки: «Пиковая дама» П. Чайковского в постановке А. Галибина // Культура и искусство. - 2011. - 5. - С. 94 - 98.

9. Розин В.М. Становление и теоретическое осмысление в культуре Нового времени классической музыки // NB: Культуры и искусства. - 2013. - 3. - С. 114 - 184. DOI: 10.7256/23061618.2013.3.9458. URL: http://www.e-notabene.ru/ca/article_9458.html.

${ }_{27}^{27}$ Рэн А. Романтический манифест. Философия литературы. М., Альпина Паблишер, 2011. С. 115 


\section{Культура и искусство 1(19) • 2014}

\section{References (transliteration):}

1. Voronina T.S.Shekspirovskaya galereya Dzhona Boidella.-V kn.: Magiya literaturnogo syuzheta. problemy interpretatsii v izobrazitel'nom iskusstve. M., Pamyatniki istoricheskoi mysli, 2012.

2. Koz'yakova M.I. Istoriya. Kul'tura. Povsednevnost'.M., Soglasie, 2013.

3. Kolchigin S. Burya v mirovozzrenii Shekspira http://www.proza.ru/2011/o9/23/669.

4. Koryabin I. Opera «Burya» Tomasa Adesa v Metropoliten-opere//URL http://www.belcanto.ru/ 12120302.html.

5. Rend A. Romanticheskii manifest. Filosofiya literatury. M., Al'pina Pablisher, 2011

6. U.Shekspir. Burya.-v kn.: Ves' Shekspir. M., OLMA-PRESS, 2002.

7. Anu Mand. Bernt Notke. Between Innovation and Tradition. Tallinn 2010.

8. D. Yu. Gustyakova Massovaya kul'tura kak kontekst opernoi postanovki: «Pikovaya dama» P. Chaikovskogo v postanovke A. Galibina // Kul'tura i iskusstvo. - 2011. - 5. - C. 94 - 98.

9. Rozin V.M. Stanovlenie i teoreticheskoe osmyslenie v kul'ture Novogo vremeni klassicheskoi muzyki // NB: Kul'tury i iskusstva. - 2013. - 3. - C. 114-184. DOI: 10.7256/2306-1618.2013.3.9458. URL: http://www.e-notabene.ru/ca/article_9458.html. 